\title{
Suppression of dominant insect pests and yield of sesame with plant materials in different climatic conditions
}

\author{
K.N. Ahmed ${ }^{1}$, S. H. A. Pramanik ${ }^{2}$, M. Khatun ${ }^{2}$, M. R. Hasan ${ }^{1}$, L. C. Mohanta ${ }^{1}$, T. Hoq ${ }^{1}$ and S. K. Ghose ${ }^{3}$ \\ ${ }^{1}$ BCSIR Laboratories, Dhaka \\ ${ }^{2}$ BCSIR Laboratories, Rajshahi \\ ${ }^{3}$ N.B. Degree College, Dhaka
}

\begin{abstract}
Sesame (Sesamum indicum L.) is an annual herb not extensively cultivated in Bangladesh. The jute hairy caterpillar, Spilarctia (=Spilosoma) obliqua (Walker) was found to attack the foliages including tender shoots of sesame in the Oilseeds Cultivation Centre of BCSIR Laboratory Campus, Rajshahi. The other pests encountered were pentatomid bugs, Dolycoris indicus (Stal) and Nezara viridula (L.), a chrysomelid beetle, Aphthona nigrilabris (Duvivier), leaf sucking coleopteran beetle and Monolepta signata (Oliv.) The insect pests encountered in the Oilseeds Cultivation Centre, Patgram, Lalmonirhat were: a pyrrhocorid bug, Dysdercus koenigii Fab. and a pentatomid bug, Piezodorus hyubneri Gmelin (Fab.). The efficacy of five plant extracts or botanicals e.g., Bara Bishkatali (Polygonum orientale L.) leaf, custard apple (Annona squamosa L.) leaf, castor (Ricinus communis L.) seed oil and sesame oil (Sesamum indicum), a mixture of Neem (Azadirachta indica L.) seed oil and sesame oil have been evaluated for their pesticide action in the suppression of dominant insect pests of sesame. The treatment of custard apple leaf extract produced significant result in pest control and crop yield next to sesame oil. Other treatments also exhibited better results in comparison to the control. The yields were 858 and $642 \mathrm{~kg}$ per acre in the crop fields of Lalmonirhat and Rajshahi districts respectively.
\end{abstract}

Keywords: Sesame; Botanicals; Insect pest suppression; Yield; Climatic conditions

\section{Introduction}

In Bangladesh, cultivation of sesame stands next to mustard. It is an annual herb, $1-2 \mathrm{~m}$ tall producing capsules containing small black seeds. The seeds contain $45-55 \%$ protein. The oil is used for preparing salad, in soaps, paint, medicines perfumes and as a synergist for pyrethrum (Hill 1983). It can also be used in biscuits and cakes to make them palatable. The oil-cake of sesame is beneficial to health for bullocks and cows (Rikabder 1987). According to Dimetry and Fatma et al. (1997) sesame oil can be used as synergist against cowpea aphid, Aphis craccivora Koch.

In crop condition, sesame is attacked by a number of insect pests viz., the jute hairy /,caterpillar, Spilarctica obliqua (Walker), pentatomid bugs viz., Nezara viridula Fab., Piezodorus hyubneri Gmelin, a pyrrhocorid bug, Dysdercus koenigii, leaf sucking coleopteran, Monolepta signata and some unidentified hemipteran bugs and a tender stem sucking coleopteran beetle (Bundy et al. 2000, Ahmed 2002).

The present work deals with the suppression of the insect pests of sesame by spraying different potential plant extracts and their impact on yield in pre-harvest conditions.

\section{Materials and methods}

In February 2011, Jamalpur variety of sesame seed collected from Bangladesh Agricultural Development Corporation
(BADC) Regional Centre, Meherpur was sown in the Oilseeds Cultivation Centre, BCSIR Laboratory Campus, Rajshahi and Oilseeds Cultivation Centre, Patgram, Lalmonirhat. Five indigenous plant extracts or botanicals were selected for application against insect pest attack in sesame crops prior to outbreak of severe infestation. The names of these botanicals sprayed were: i) Bara Bishkatali (Polygonum orientale L.) leaf, ii) custard apple (Annona squamosa L.) leaf, iii)castor oil (Ricinus communis L.),iv) sesame oil (Sesamum indicum L.) and v) a mixture of Neem seed (Azadirachta indica L.) oil. These were sprayed in the western and northern Oilseeds cultivation Centres of Rajshahi and Lalmonirhat districts. The leaf extracts of above mentioned indigenous plants were used for spraying. Sesame fields of both the Centres were divided into six plots including control and above mentioned plant extracts were sprayed prior to pest out-break. Six plots were chalked out to render them fit for randomized block design. Different insect pests were collected fortnightly from different locations e.g., front, middle and rear portions of each plot randomly having infested sesame plants.

The different treatments were symbolized as follows:

A control treatment

B Bara Bishkatali leaf treatment

C custard apple leaf treatment

D castor oil treatment

*Corresponding author. e-mail: knahmed2010@yahoo.com. 
E Neem seed oil and treatment

F Neem seed oil and Sesame oil treatment

The pests were collected in both the sesame fields of Patgram and Rajshahi at fortnightly. These were preserved in $80 \%$ ethanol. The status of pest occurrence in sesame crop fields before and after spraying was carefully recorded. The data on yield of seed per plant, plant height and number of seeds per plant were recorded. The impact of plant extracts on yield was predicated. The prevailing field temperatures and relative humidity in both the fields of sesame were also recorded.

\section{Results and discussion}

Results on the influence of different plant extracts on the number and size of capsules (fruits) and yield per plant in BCSIR Lab Centre, Rajshahi and Patgram, Lalmonirhat centres are presented in the Table I. It is evident that variance ratio ( $\mathrm{F}$ value) is significant at $1 \%$ level. It indicates that, there are remarkable effects of plant extracts on the size and number of fruits in sesame plants. The applied plant extracts exhibited its great impact on the size and number of pod (fruit) formation in sesame crop. The variance ratio, F- value was found to be 20.01 with significant $P$ value $((P<0.001)$. It reveals that indigenous plant extracts or botanicals produced significant results on the yield of sesame when sprayed on the sesame plants during cultivation.

During pest infestation in the BCSIR Laboratories Campus, Rajshahi, three plant extracts from plant source viz., custard apple leaf extract, Bara Bishkatali leaf extract and a mixture of Neem seed oil and sesame oil were applied. The insectpests that attacked the sesame plants and the capsules (fruits) were collected and preserved in $80 \%$ ethanol with a drop of glycerine. The major insect pests recorded were: Spilarctia obliqua, Nezara viridula and Monolepta signata. The maximum yield per plant of sesame was $21.4 \mathrm{gm}$ in the treatment of custard apple leaf extract. On the other hand, minimum yield of 5.9 gm was observed on Bara Bishkatali leaf extract (Table II). A maximum number of 163 pods per plant were produced in custard apple treatment whereas only 53 pods were observed in the treatment of Bara Bishkatali leaf extract. The yield of sesame was 16.0 maunds per acre.

The impacts of different plant extracts on the number of capsules and yield per sesame plant are shown in Table I. Duncan's New Multiple Range Test (DNMRT) was applied to show the significant differences among the means. Spilosoma obliqua (Walker) is a polyphagous pest that attacks a wide range of plants. The pentatomid stink bug, Nezara viridula occurred both in the sesame crop fields of Rajshahi and Patgram which sucked the tender shoots and destroyed the immature fruits. According to Bundy et al. (2000), Nezara viridula pierced the cotton bolls and destroyed the immature fruits. Another pentatomid bug, Dolycoris indicus also sucked the foliage and tender fruits in both the crop fields. However, Ahmed et al. (1989) recorded it as a pest of groundnut sucking the tender leaves and flower buds. In the sesame field of Patgram, Lalmonirhat, a pyrrhocorid stink bug named Dysdercus koenigii (Fab.) pierced the immature capsules (fruits) of sesame and this pest was not encountered in BCSIR Lab field, Rajshahi. According to Hill (1983), it is a serious pest of cotton bolls and also attacks many plants and trees including sorghum, and Hibiscus sp.

During present study, it is revealed that sandy and loamy soil of Patgram, Lalmonithat Centre was suitable for sesame cultivation and enhanced production of its yield, Chauhan et al. (1999) reported that sesame can be sown as a rain-fed post-

Table I. Effect of different botanicals on the yield of sesame in BCSIR and Lalmonirhat oilseed cultivation Centres

\begin{tabular}{lccc}
\hline Treatment & Centre & \multicolumn{2}{c}{ Mean \pm S.E } \\
\cline { 3 - 4 } & & No. of plot/plant & Yield of Sesame (g) per plant \\
\hline A (Control) & BCSIR & $87.5 \pm 4.24 \mathrm{a}$ & $8.68 \pm 0.33 \mathrm{a} *$ \\
& Lalmonirhat & $114.9 \pm 21.96 \mathrm{~b}$ & $18.27 \pm 5.78 \mathrm{c}$ \\
B & BCSIR & $79.81 \pm 7.82 \mathrm{a}$ & $8.82 \pm 0.77 \mathrm{a}$ \\
$(10 \%$ Polygonum orientale leaf $))$ & Lalmonirhat & $79.9 \pm 12.44 \mathrm{a}$ & $12.67 \pm 1.98 \mathrm{~b}$ \\
C & BCSIR & $131.8 \pm 6.08 \mathrm{c}$ & $17.23 \pm 1.21 \mathrm{c}$ \\
$(10 \%$ Annona squamosa leaf $)$ & Lalmonirhat & $146.6 \pm 17.66 \mathrm{~d}$ & $23.31 \pm 2.81 \mathrm{db}$ \\
D & & & \\
$(10 \%$ Ricinus communis $)$ & Lalmonirhat & $83.2 \pm 13.6 \mathrm{a}$ & $13.20 \pm 2.16 \mathrm{~b}$ \\
E & & & \\
$(10 \%$ Neem seed oil+Sesame seed oil) & Lalmonirhat & $116.4 \pm 18.96 \mathrm{~b}$ & $18.47 \pm 3.04 \mathrm{c}$ \\
$(10 \%$ Azadirachta indica $)$ & BCSIR & $98.3 \pm 9.08 \mathrm{~b}$ & $11.6 \pm 1.02 \mathrm{~b}$ \\
& Lalmonirhat & $94.6 \pm 15.76 \mathrm{~b}$ & $15.01 \pm 2.5 \mathrm{c}$ \\
\hline
\end{tabular}

\footnotetext{
* The means followed by the same letter are not significantly different by Duncan's Multiple Range Test.
} 
Table II. Pest occurrence during the month February, March and April, 2001 in BCSIR and Lalmonirhat Oilseed Cultivation Centres under prevailing field conditions.

\begin{tabular}{|c|c|c|c|c|c|}
\hline $\begin{array}{c}\text { Name of the insect } \\
\text { pest }\end{array}$ & Order with family & Centre & Treatment & Pest status & $\begin{array}{l}\text { Total nos. of insect pests } \\
\text { collected in } 3 \text { months at } \\
\text { fortnightly interval }\end{array}$ \\
\hline \multirow{12}{*}{$\begin{array}{l}\text { 1. Spilosoma obli- } \\
\text { qua (Walker) }\end{array}$} & \multirow{12}{*}{$\begin{array}{l}\text { Lepidoptera: } \\
\text { Arctiidae }\end{array}$} & BCSIR & Control & 1st instar larvae & 250 \\
\hline & & Lalmonirhat & & & 180 \\
\hline & & Do & $\mathrm{B}$ & Mature larvae & 65 \\
\hline & & & & Mature Larvae & 40 \\
\hline & & Do & $\mathrm{C}$ & and adult moth & 23 \\
\hline & & & & & 12 \\
\hline & & Do & $\mathrm{D}$ & Do & 87 \\
\hline & & & & & 50 \\
\hline & & Do & $\mathrm{E}$ & Do & 25 \\
\hline & & & & & 48 \\
\hline & & Do & $\mathrm{F}$ & Do & 40 \\
\hline & & & & & 23 \\
\hline \multirow{13}{*}{$\begin{array}{l}\text { 2. Nezara viridula } \\
\text { (L.) }\end{array}$} & \multirow{12}{*}{$\begin{array}{l}\text { Hemiptera: } \\
\text { Pentatomidae }\end{array}$} & Do & $\mathrm{A}$ & Adult & 40 \\
\hline & & & & & 55 \\
\hline & & Do & $\mathrm{B}$ & Do & 25 \\
\hline & & & & & 20 \\
\hline & & Do & $\mathrm{C}$ & Do & 12 \\
\hline & & & & & 15 \\
\hline & & Do & $\mathrm{D}$ & Do & 48 \\
\hline & & & & & 35 \\
\hline & & Do & $\mathrm{E}$ & Do & 26 \\
\hline & & & & & 20 \\
\hline & & Do & $\mathrm{F}$ & Do & 21 \\
\hline & & & & & 18 \\
\hline & \multirow{12}{*}{$\begin{array}{c}\text { (Coleoptera: } \\
\text { Chrysomelidae) }\end{array}$} & Do & $\mathrm{A}$ & Do & 43 \\
\hline \multirow{11}{*}{$\begin{array}{l}\text { 3. Aphthona } \\
\text { nigrilabris } \\
\text { (Duvivier) }\end{array}$} & & & & & 35 \\
\hline & & Do & $\mathrm{B}$ & Do & 20 \\
\hline & & & & & 24 \\
\hline & & Do & $\mathrm{C}$ & Do & 15 \\
\hline & & & & & 17 \\
\hline & & Do & $\mathrm{D}$ & Do & 26 \\
\hline & & & & & 23 \\
\hline & & Do & $\mathrm{E}$ & Do & 22 \\
\hline & & & & & 25 \\
\hline & & Do & $\mathrm{F}$ & Do & 21 \\
\hline & & & & & 24 \\
\hline \multirow{12}{*}{$\begin{array}{l}\text { 4. Dysdercus } \\
\text { koenigii (Fab.) }\end{array}$} & \multirow{12}{*}{$\begin{array}{l}\text { Hemiptera: } \\
\text { Pyrrhocoridae }\end{array}$} & Do & $\mathrm{A}$ & Do & 43 \\
\hline & & & & & 68 \\
\hline & & Do & B & Do & 30 \\
\hline & & & & & 48 \\
\hline & & Do & $\mathrm{C}$ & Do & 27 \\
\hline & & & & & 20 \\
\hline & & Do & $\mathrm{D}$ & Do & 40 \\
\hline & & & & & 52 \\
\hline & & Do & $\mathrm{E}$ & Do & 38 \\
\hline & & & & & 43 \\
\hline & & Do & $\mathrm{F}$ & Do & 32 \\
\hline & & & & & 36 \\
\hline
\end{tabular}


Table III. Temperature, relative humidity, rainfall etc. BCSIR and Lalmonirhat sesame cultivation centres under field conditions

\begin{tabular}{|c|c|c|c|c|c|c|c|c|}
\hline \multirow[t]{2}{*}{ Months } & \multicolumn{2}{|c|}{ Average Temperature } & \multicolumn{2}{|c|}{ Relative Average humidity (\%) } & \multicolumn{2}{|c|}{ Rainfall } & \multicolumn{2}{|c|}{ Weather condition } \\
\hline & Rajshahi & Lalmonirhat & Rajshahi & Lalmonirhat & Rajshahi & Lalmonirhat & Rajshahi & Lalmonirhat \\
\hline February & 12.5 & 8.3 & 65 & 57 & Nil & Nil & foggy & Heavy foggy \\
\hline March & 25 & 21 & 70 & 63 & Nil & Nil & Mist & Heavy mist \\
\hline April & 28 & 23 & 80 & 75 & Nil & Nil & Sunny & Cloudy \\
\hline
\end{tabular}

rice crop in farmer's fields. According to Khan et al. (1991), sesame crop sown during July exhibited maximum seed yield $(1246.66 \mathrm{~kg} / \mathrm{ha})$ while 15 th August sowing date showed maximum oil contents $(54.8 \%)$. However, the nitrogen level favourably influenced the productivity of sesame in the present investigation. This finding complies with the view of Parihar et al. (1999).

According to Rahman et al. (2000), grated garlic and its volatile extract applied on brown rice showed a repellent effect but no insecticide activity against stored product pests, i.e., maize weevil and the red flour beetle. Tashiro et al. (1991) reported that alkaloid contents namely sesamin and sesamolin of sesame break down into other substances prior to full maturity of the capsules. During present study, Polygonum orientale L. (Bara Bishkatali) leaf extract showed greater yield of $8.82 \pm 0.77$ and $12.67 \pm 1.98$ gm per sesame plant (Table I) in oil seed cultivation Centres of Rajshahi and Lalmonirhat respectively. Jena (2000) described that Plygonum hydropiper extract proved effective against rice pest, Nilaparvata lugens Stal.

\section{Acknowledgements}

The authors are grateful to the Ministry of Science and Technology for granting special allocation of Tk six lacs during the financial years 1999-2000 and 2000-2001 for conducting the research work. The author thankfully recalls the cooperation of the Ex-Director, Dr. Md. Golbar Hussain, BCSIR Laboratories, Rajshahi during the course of investigation.

\section{References}

Ahmed KN, Hussain MM and Islam U (1989), A preliminary report on the insect pests of groundnut. J. Asiat. Soc. Bangladesh, Sci. 15: 31-35.

Ahmed KN (2002), Use of Biopesticide in the control of the pests of oilseeds in preharvest and postharvest conditions. (2002). Unpubl. Final Report. Submitted to the Ministry of Science and Technology for the financial year, 2000-2001.

Biswas GC and Das GP (2004), Natural enemies of the insect pests of sesame and their succession. J.Asiat. Soc, Bangladesh, Sci. 30: 41-48.
Bundy CS, Mcpherson RM and Herzog GA (2000), An examination of the external and internal signs of cotton boll damage by stink bugs (Hemiptera: Pentatomidae). Jour. Entomol. Sci. 35: 402-410.

Chauhan YS, Atukorala WD, Perea KDA, Joseph KDSM Saxena KB and Johansen C (1999), Adaptation of extra-short duration pigeonpea in the short rainy season of a tropical bimodal rainfall environment. Exp. Agric. 35: 87-100.

Dimetry NZ and Fatma MA El-Hawary. (1997), Synergistic effect of some additives on the biological activity and toxicity of neem-based formulation against the cowpea aphid, Aphis craccivora Koch. Insects Sci. Appl. 17: 395-399.

Hill DS (1983), Agricultural insect pests of the tropics and their control. 2nd ed. Cambridge Univ. Press, London. $746 \mathrm{pp}$.

Jena M (2000), Efficacy of the plant, Polygonum hydropiper against rice brown plant hopper, Nilaparala lugens Stal. curr. sci. 78: 953-954.

Khan AH, Sheikh AH, Din F, Khan MI and Hamid S (1991), Sowing schedules effect on yield and oil contents. $J$. Agric. Res. (Pakistan). 29: 61-64.

Rahman GK, Mustafizur M and Motoyama N (2000), Repellent effect of garlic against stored product pests. Pesticide Sci. 25: 247-252.

Rikabder FH (1987), Tel shasher Utpadan Kola-kowshal, Agriculture Information Service, Ministry of Agriculture, Dhaka-1000.

Parihar SSD, Pandey and Shukla RK (1999), Response of summer sesame (Sesamum indicum) in irrigation schedule and nitrogen level in clay-loam soil. Intl. Trop. Agric. 17: 189-193.

Tashiro T, Fukuda Y and Osawa T (1991), Oil contents of seeds and minor components in the oil of sesame, Sesamum indicum L., as affected by capsule position. Japanese J. Crop Sci. 60:116-121.

Received: 22 November 2012; Revised: 07 November 2013; Accepted: 02 March 2014. 